\title{
人間型ロボット開発に括ける 技術戦略*
}

\section{[明日の扉を開く技術戦略］}

\section{比留川博久**}

R \& D Starategy of Humanoid Robotics / Hirohisa HIRUKAWA

Key words: Humanoid Robots, Roadmap, Applications

\section{1. はじめに}

本田技研は, 1986 年から秘密裏に人間型ロボットの開 発を実施し，1996 年にその成果である P2 を発表して世の 中を警かせた。P2の衝撃は専門分野が近い人程大きく, 特定の技術に大規模な投資をすれば，従来困難であるとさ れていた問題でも克服が可能であることを改めて思い知ら せた。この様な民間の先行投資の刺激を逆に受けて，経済 産業省は 1998 年から 5 年間「人間協調・共存型ロボット システム研究開発プロジェクト (Humanoid Robotics Project, HRP)」を実施し，人間型ロボット基盤技術を開発 するとともに，その応用可能性の実証を行った。また，ソ ニーは明確に応用分野をエンターテインメントに絞り, 2000 年から SDR-3X, SDR-4X, SDR-4XII を相次いで発表, 今年になって SDR-4XII に QRIO という商品名も付けて, 商品化が近いことを匂わせている.

人間型ロボット関連技術は，これまでの官民の大規模投 資により我が国が他を大きく引き離している状態である. 一方, 現時点で明確な市場が見えているとは言い難く, 引 き続き大規模な投資を継続するためには明快な技術戦略が 必須である。本稿では，経済産業省のプロジェクトの成果 を踏まえて，筆者が描く技術戦略について述べる。

\section{2. 経済産業省のプロジェクトの成果}

\section{1 プラットフォームの開発}

前述した $\mathrm{HRP}$ (プロジェクトリーダ：井上博允東大教授） では, 人間型ロボットの研究開発基盤, プラットフォーム の開発を行った。プラットフォームは, 人間型ロボットハ

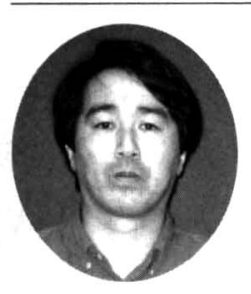

* 原稿受付 平成 15 年 10 月 16 日

**産業技術総合研究所（つくば市梅園 1-1-1つく ば中央第 2)

比留川博久

1987 年神戸大学大学院自然科学研究科システ 么科学専攻博士課程修了。学術博士. 同年電子 技術総合研究所入所，現在改組により現職。こ の間、スタンフォード大学客員研究員. ロボッ トの知能化、人間型ロボット等の研究に従事。
ードウェア HRP-2（図 1) 扰よびソフトウェアプラットフォ 一ム OpenHRP(図 2)から構成される。

これらプラットフォーム開発の狙いは，人間型ロボット の技術開発の裙野を拡げることである。人間型ロボットを 実用化するためには，多種多様な技術がその上に集積され る必要があるが，本田技研やソニーのロボットを使えるの は原則として自社の技術陣に限られている。 HRP-2 と OpenHRPの開発により，人間型ロボット関連技術の開発 により容易に参入可能となった。実際、これまで複数の大 学の研究室が HRP-2 を購入し, 研究開発を開始している. この点が，民間企業が大規模投資をしているにも拘らず， 公的な研究開発が必要であった理由の一つである。

プラットフォームの効用が足し算にあることは自明であ る. 提供されたプラットフォームの上に自身の技術を付加 することができるので，開発の効率を上げることが可能に なる.プラットフォームのもう一つの効用は引き算である。 例えば，独自の運動制御ソフトウェアを開発し，HRP-2の 上で検証することもできる．HRP-2 が歩行可能なことは検 証済であるので，上手くいかないときは自分の責任である ことが分かる. 本田技研の $\mathrm{P} 2$ の様な完成度の高いハード ウェアの登場以前には，たとえ素晴らしい制御方法があっ たとしても，それが有効かどうか検証することは困難であ ったが,今はそれが可能になった。また,運動制御ソフトウ

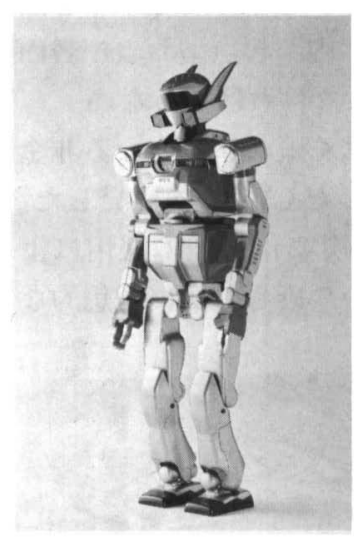

図 1 人間型ロボット HRP-2 (川田工業)

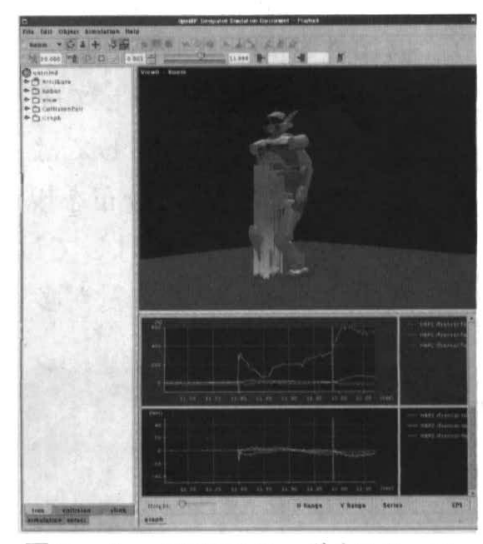

図 2 OpenHRPのユーザインターフエ イス(産総研) 
エアを構成する歩行パターンジェネレータ・フィードバッ ク制御系等の要素技術のみを入れ替えて, 比較することも 可能になった.

\section{2 応用分野の開拓}

ロボットが人間の形をしている必要性はないのではない かという指摘をしばしば受ける。我々は，人間型ロボット の特徴は次の 3 点にあると考えている.

(1) 人間の形をしていることそのものに意味がある.

(2) 人間の使う道具がそのまま使える.

(3) 人間の環境がそのまま使える.

ソニーの目指すエンターテインメントへの応用は，(1)の 特徴を活かしたものである。ロボットが人間の形をしてい て，二足で歩いたり，ダンスをしたりするからエンターテ インメントになるのである。これが車輪型だと人々の興奮 の程度は遥かに低くなる。

HRPでは，(2)の特徴を活かした応用の例として，産業 車両等の代行運転を取り上げた。これは，遠隔操作された 人間型ロボットに，フォークリフトやバックホーの運転を させようというものである。たとえば，災害救助作業の際 に，安全な場所にいる人間が遠隔操作するロボットに，バ ックホー等を運転させ， 2 次災害を避けようという考えで ある。この様子を図 3 に示す。

人間型ロボットを使う代わりにバックホーを改造すれば よいのではないかという指摘もしばしば受ける。我々の主

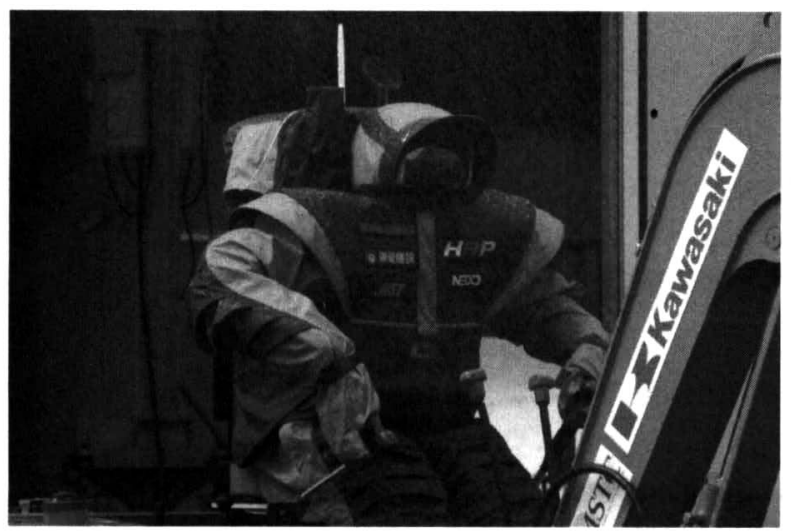

図３パックホーを運転する人間型ロボット (川崎重工，東急建設，産総研)

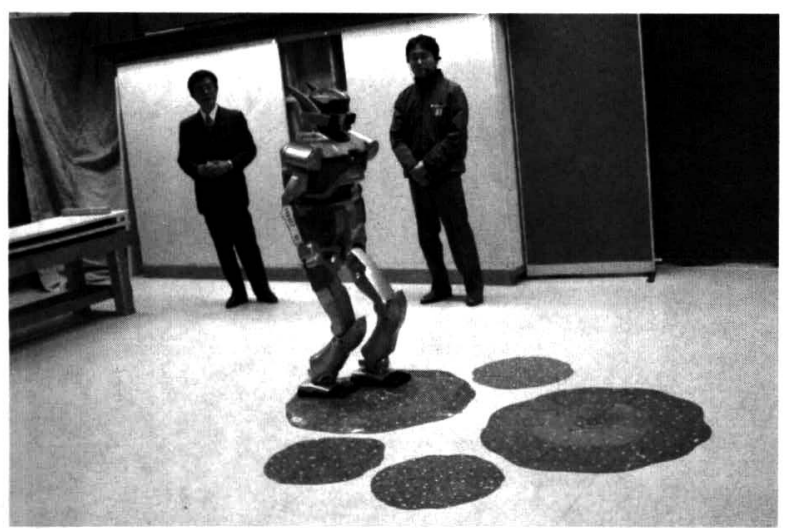

図 4 不整地を歩くHRP-2（産総研）
張は、次の通りである。

・機械の改造はそれぞれ個別に行う必要があるが，人間 型ロボットは様々な機械の運転が可能である.

・人間型ロボットは運転だけでなく, 降車して別の作業 を行うことも可能である.

現時点では，専用の改造を行う方がコスト的には有利で あるが，人間型ロボットの技術がさらに発展し，量産可能 となれば，逆転する可能性があると考えている。

HRPでは，(3)の特徴を活かした応用例として，産業用 プラントの保守・点検作業, 屋外共同作業, ビル・ホーム の留守管理，介助等の対人サービスを取り上げた。プラン トの保守・点検では，階段や段差・ピット等のある環境， 屋外共同作業では不整地路面を人間の使う環境の特徴とし て取り上げ，これらの環境での移動技術の検証を行った。 不整地を歩いている HRP-2の様子を図 4 に示す。これま で，段差 $4 \mathrm{~cm}$ 以内，傾斜 $5 \%$ 以内の不整地の歩行に成功 している.

階段や段差，不整地を移動できるというのは車輪型等と 比較した長所であるが，一方で二足歩行ロボットは重心の 位置が相対的に高いため，転倒の危険が高いという短所を 持っている。一般に，既存の技術と比較して長所はあるが 短所もある技術はなかなか社会に受け入れられない。そこ で，HRPでは転倒した場合にも破損を最小限に抑えるため の転倒制御技術，転倒した場合に再び起上るための転倒回 復技術の開発を行った。転倒回復動作の例を図 5 に示す.

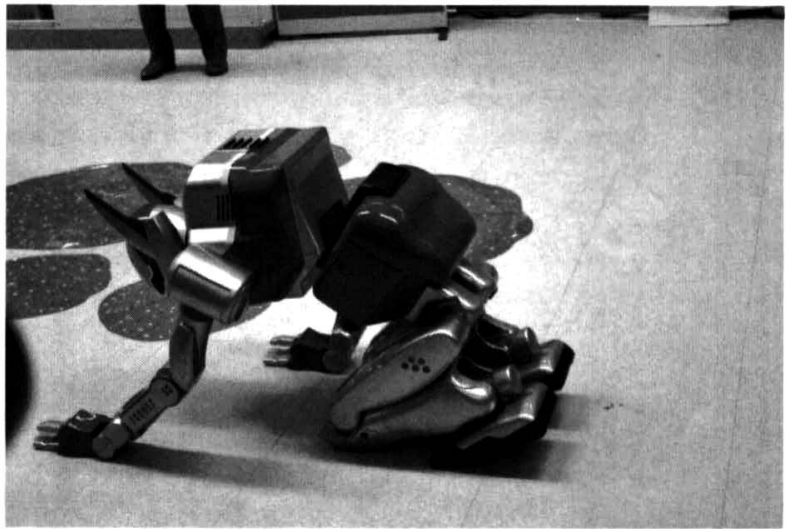

図 5 HRP-2 の転倒回復動作

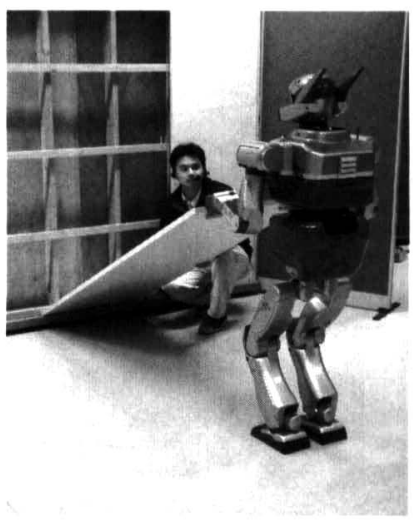

図 6 パネル建付计作業をする HRP-2 (安川電機, 川田工業, 清水建設, 産総研) 
また，人間と共同でパネルの建付け作業をしている HRP-2の様子を図 6 に示す.

以上述べた様に, HRP は人間型ロボットの特徵を活かし た応用可能性の検証を行い，一定の成果を得てきている.

\section{3. 人間型ロボット開発における技術戦略}

\subsection{5 年後の目標}

前述した様に，人間型ロボット関連技術は我が国が世界 を大きくリードしているが，それでもいわゆる「死の谷」 を経ることなく産業化に至る道は平坦ではない．大規模な 投資を必要とする故, 5 年程度のスパンで何らかの応用の 実現を目指す必要がある。もしも人間と同じことができる ロボットを目指したら，少なくとも今世紀中は要するであ ろう。機能を限定したとしても，自律作業機能の実現には 10 年以上かかるものと思われる.

そこで，5年後の目標として，次のものを掲げている. 「通常環境の路面を踏破し，階段と梯子を昇降し，自律的 に移動経路を決定し，転倒しても運動機能は城失せず，再 び起上って歩行し，小さな障害物は跨ぎ越え，狭险部を潜 り抜け，ドアを自分で開閉し，片腕で体を支えながら作業 できるような人間型ロボットの実現」

一言で言うと，「普通の人間が行けるところには行ける」 人間型ロボットである。この様なロボットができると，例 えば危険なプラントの点検作業 (図 7 参照) や，危険物処理 作業(図 8 参照)等の実現の可能性が高まってくる.

この中で最も実現が困難なのは「転倒しても運動機能は

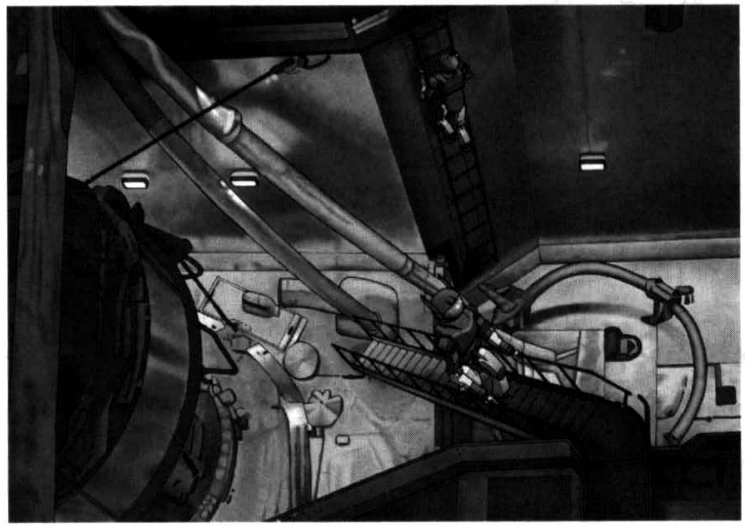

図 7 プラント点検作業のイメージ

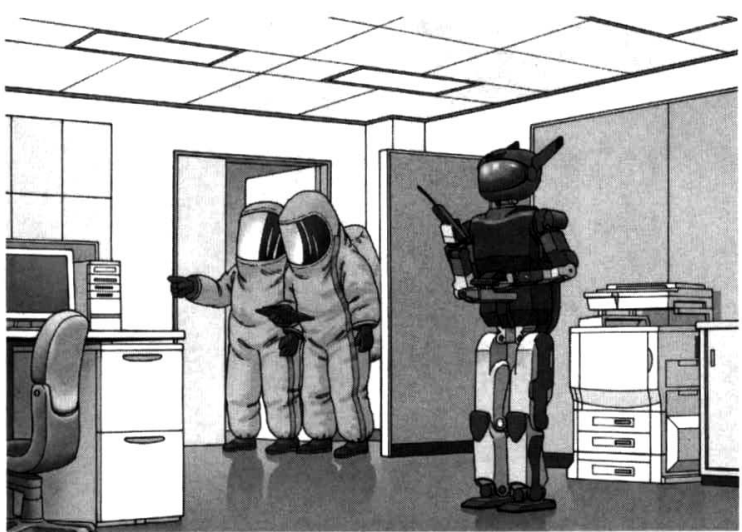

図 8 危険物処理のイメージ
喪失せず」という点である，現在のところ，破損を最小限 に抑えるための転倒制御を適用したとしても，転倒時の衝 撃に十分なリスクマージンを持って耐えるハードウェアを 実現することは容易ではない，最も投資が望まれる点であ る.

上記の応用に関しては, 作業は全てが自律で行える必要 はなく，非定型作業は遠隔操作で十分である。ロボットの 単価は 2,000 万円以下, 100 台程度の生産が目標である.

\subsection{0 年後の目標}

次の目標は，「普通の人間なら行える簡単な作業の自律 的な実行」である。このためには，作業対象の形状・位 置・姿勢を捉える 3 次元視觉技術, 実際の作業に耐える八 ンド, 物体の把持状態を知るための力触覚センサ, 作業計 画技術等の実現が必要である.

これらの技術により，大規模構造物の分解作業(図 9 参 照)等の実現可能性が高まってくる. 特に, ダイオキシン が問題となっている焼却炉の廃炉作業に利用できるとその 意義は大きい.

ここまでくると応用範囲はかなり拡がるので，ロボット の単価は 1,000 万円以下， 1,000 台規模の生産も視野に 入ってくる.これが実現すれば，人間型ロボットは「死の 谷」を越えたと言えるであろう。

\subsection{5 年後の目標}

最後に目標とするのは，人間と同じ空間に共存し，協調 して働くことのできる人間型ロボットである。これが実現 して始めて，HRPの最終目標が達成されたことになる。

この実現のためには，高い作業能力とともに，人間や周 囲の環境を傷つけない高い安全性の実現が要求される。移 動や作業のためには大きなパワーが必要とされるので, こ れと安全性を両立させるのは容易ではない，人間どうしで も, 過って周りの人を傷つけてしまうことはある.人間ど うしでも問題であるが， ロボットの場合には完璧な安全性 が要求される。単にパワーを落としたり，柔軟なカバーを 付けたりするだけでは不十分で，環境の実時間認識技術や 制御技術の総合技術により, 目標の安全性が達成される可 能性が出てくるものと考えられる.

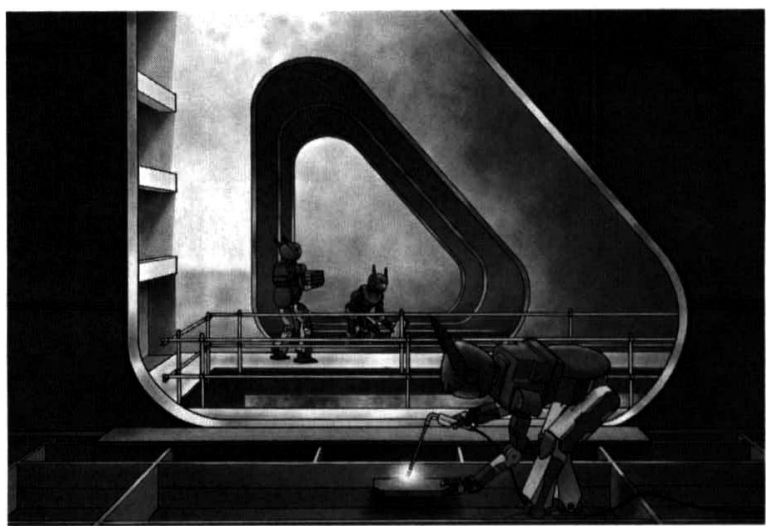

図 9 大規模構造物分解作業のイメージ 


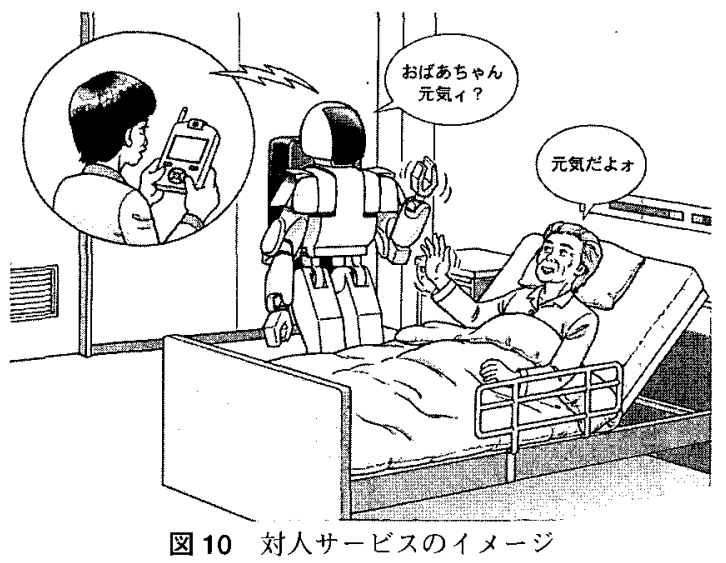

この様な高い作業能力と安全性が実現されたら，HRP で研究を進めた対人サービス (図 10 参照) 等の実現可能性 が出てくる，厹の実現は容易ではないが，成功した場合に はその市場は最も大きく，最終的には一家に一台という普 及も夢ではないであろう。この場合,ロボットの単価は 100 万円以下，生産数は数万台から数十万台になる可能性があ る.

誤解のない様に確認しておくが，人間型ロボットが 100 万円になれば 100 万台売れます，と主張しているのでは決 してない，言いたいことは逆で，「100万台売れるだけの 応用の要求を満たす技術が開発できれば，単価は 100 万円 になるでしょう」ということである。この単価について懐 疑的な意見もあるが，現在の人間型ロボットの部品点数は 数千点で, 部品点数・必要な材料の量とも自動車より少な いものと思われる，自動車が 100 万円で作れるのであるか ら，人間型ロボットも作れるはずである。

\section{4. 今後の展望}

人間型ロボットの産業化への道が平坦ではないのは筆者 自身も認識しているが，一旦研究開発が途絶えてしまうと， よしんば何年か後に復活したとしてもそのときには我が国 の優位性は失われているであろう。そうなると，これまで の官民の努力が水泡に帰してしまう．何とか実現可能な応 用を見つけたいと我々自身も地道な研究開発を継続してい る.

5 年後を目指した研究開発としては，川田工業や川崎重 工とともに，実環境で使える人間型ロボット基盤技術の開 発を行っている。具体的には，防塺防滴処理を施され，滑 りやすい路面上も歩行できるロボットの開発，遠隔操作技 術の開発等を行っている。10 年後を目指した研究開発と しては, 産総研内の情報処理関連研究グループと共同して, 視覚や聴覚等の知能化技術を人間型ロボット上に集積する プロジェクトを開始した。

我が国の産業用ロボットの市場規模は 1980 年頃から 20
年問，1 年あたり 5,000 億円から 6,000 億円の範囲で推移 し，横ばい状態にある。市場が伸びなかった最大の理由は， ロボットにできる仕事の種類が大きく増えなかったこと， さらに元を辿れば，できる仕事の種類を増やすための技術 が伸びなかったことにある。

筆者が考える処方箋は，次の 2 点である.

・研究者自身が応用調查を真剣にやること．新しい応用 が最先端の技術で実現可能かどうかは，専門家にしか 判断できない，研究者自身が現場に出かけていき，そ の実現可能性を真剣に考える努力が必要である.

・技術の完成度を高める努力をすること．これまで多く の新しい技術が論文レベルでは提案されてきているが， 実用に耐える完成度を持つものは少ない，応用調查結 果に基づいて，有望なものに集中投資する必要がある。 本田技研の二足歩行技術が良い手本である。

我々自身も，消防や警察，建設現場等に出かけていって， 応用の探索をしている. 残念ながら，現時点では決定的な 解は見出せていないが，不断の努力を続けていきたいと考 えている。

燃料電池の様に，開発に成功すればその有用性に疑問の 余地がない技術に対して大規模投資をするのは比較的容易 であるが，人間型ロボットの様に応用分野そのものを合わ せて開拓しなければならない技術への大規模投資は，より 勇気を必要とする。本田技研，ソニー等の民間企業の努力 に拍手を送るとともに，我々自身も何とか開発を継続して いきたいと願っている。

20 世紀最大の商品は，招そらく自動車であったろうと 思われる。自動車は「遠くへ行きたい」「運転すること自 体が楽しい」という人間の根源的欲求に応えていたため, これだけ普及したのであろう。では，人間型ロボットは人 間のどういう欲求に応えてくれるのであろうか。筆者の答 えは，「自分のやりたくないことを代わりにやってくれる」 「一緒にいること自体が楽しい」の 2 点である。よく言わ れることではあるが，今後超高齢化社会を迎える我が国に おいては，こ扎らの欲求を満たすことが深刻に必要になる ものと考えている.

\section{謝辞}

HRP プロジェクトリーダを務められた井上博允氏 (東 大），プロジェクト関係者に感謝します。

\section{関連ホームページ}

1) HRP, http://www.mstc.or.jp/hrps/main.html

2) HRP-2, http://www.kawada.co.jp/ams/promet/

3）本田技研 ASIMO, http://www.honda.co.jp/ASIMO/

4) ソニ-QRIO, http://www.sony.co.jp/SonyInfo/QRIO/

5）産総研知能システム研究部門ヒューマノイド研究グループ, http://www.is.aist.go.jp/ 